\title{
“'n Onselfstandige gesin beteken 'n onselfstandige volk": Organiese nasionalisme en die amptelike gesinsbeleid van die Ossewa-Brandwag
}

\section{Charl Blignaut en Kobus du Pisani*}

\section{Opsomming}

Die Ossewa-Brandwag (OB) was 'n Afrikanernasionalistiese massa-organisasie wat vanaf 1939 tot 1954 bestaan het. Die beweging is gekenmerk deur 'n uiters sterk ideologie wat Afrikanernasionalisme met nasionaal-sosialistiese gedagtes verbind het. Die konsep volk het 'n beduidende invloed op OB-lede uitgeoefen. Gewapen met 'n sterk Calvinistiese ordeningsbeginsel het die ideologie van die OB die idee uitgedra van "organiese volkseenheid" wat die Afrikaner voorgestel het as deel van 'n volksorganisme.

Alhoewel daar al enkele studies gepubliseer is oor die ideologie van die $\mathrm{OB}$ is daar nog nooit indringend gelet op die leierskap en Afrikanerdenkers se gebruik van die "organiese" metafoor teen die agtergrond van die heersende intellektuele milieu nie. Voorts bestaan daar geen gepubliseerde studie wat die verband tussen organiese volkseenheid en die amptelike gesinsbeleid uitwys nie. Hierdie artikel stel dit ten doel om die oorsprong en invloed van die organiese gedagte op OB-beleid na te speur asook om die leemte te vul wat betref 'n ontleding van die OB se gesinsbeleid. Daar word bepaal watter rol die gesin gespeel het in die beweging se doelwitte en samelewingsideaal.

Dit is duidelik dat in lyn met die organiese volksgedagte, die idee van die gesin 'n kardinale rol gespeel het in die OB se doel om die samelewing te omvorm en daarmee saam is die rol van die vrou in hierdie verband by uitstek beklemtoon as integraal tot die sukses van OB-doelstellings.

Sleutelwoorde: Ossewa-Brandwag; Afrikanernasionalisme; organiese nasionalisme; gendergeskiedenis; H.G. Stoker; N. Diederichs; P.J. Meyer; gesin; vroue.

* Charl Blignaut is 'n lektor in geskiedenis wat spesialiseer in gendergeskiedenis en interdissiplinêre geskiedenis. Hy is tans besig met sy $\mathrm{PhD}$ wat gewortel is in die geskiedenis van emosies. Kobus du Pisani is 'n gegradeerde volprofessor in geskiedenis. Tientalle artikels het uit sy pen gevloei asook verskeie boeke en hoofstukke in versamelwerke. Hy is tans besig met 'n biografie van John Vorster. Beide outeurs is verbonde aan die Potchefstroomkampus van die NoordwesUniversiteit. 


\section{Abstract}

The Ossewa-Brandwag (OB) was an Afrikaner nationalist mass movement that existed from 1939 to 1954 . The organisation was characterised by a particularly strong ideology which sought to combine Afrikaner nationalism with nationalsocialist ideas. The concept of "volk" had an important influence on the members of the OB. Armed with a strong Calvinist orientation, the ideology of the OB carried within itself the ideal of the "organic unity of the nation" which saw the Afrikaner as being part of an organism of the volk.

Although a few studies have been published on the ideology of the OB, the use of the "organic" metaphor by leaders and Afrikaner intellectuals, against the backdrop of the reigning intellectual milieu, has never been analysed. Furthermore, no published study exists that focuses on the relationship between the organic unity of the nation and the movement's official family policy. This article aims to fill this gap by tracing the origin and influence of the organic idea on the official policies of the $\mathrm{OB}$ - especially on its family policy. The focus is placed on the role the family played within the organisation's aims and its ideal for a new society.

It is evident that in line with the idea of the organic volk, the idea of the family played a crucial role in the OB's aim to reform society; also emphasised is the importance of the role of women as vital for realising the aims of the movement.

Key words: Ossewa-Brandwag; Afrikaner nationalism; organic nationalism; gender history; H.G. Stoker; N. Diederichs; P.J. Meyer; family; women.

\section{Inleiding}

As beweging wat gespruit het uit die intense emosionele gevoel rondom die eeufeesviering van die Groot Trek in 1938, het die Ossewa-Brandwag (OB) 'n sterk karakter van Afrikanernasionalisme aangeneem. Die idee van "organiese volkseenheid" ${ }^{1}$ was een van die hoofkenmerke van die OB se nasionalisme. Dit het later die $\mathrm{OB}$ se beleid oor die gesin ingrypend beïnvloed in die vorm van die OB se amptelike gesinsbeleid. Daar bestaan geen studie wat diepgaande aandag gee aan hierdie beleid of die ideologiese ondertone daarvan nie. Die doel van hierdie artikel is om te bepaal hoe OB-beleid beïnvloed is deur die sogenaamde "organiese nasionalisme" en hoe laasgenoemde weer die beskouing van die rol en plek van die gesin binne die OB se samelewingsideaal beïnvloed het. Deurentyd word die organiese metafoor ontleed binne die ideologiese konteks van die OB ten einde te bepaal watter rol die idee van die gesin in die doelstellings en toekomsvisie van die OB gespeel het.

Gesinsvorming is nie in die $\mathrm{OB}$ aanvaar as proses wat vanselfsprekend plaasvind nie. Gesinne het die kern uitgemaak van die OB se idee van "organiese

1. Die problematiek rondom die konsep "volk" en "blanke" word erken, maar dit word deurentyd gebruik ter wille van die outentiekheid en konteks van die tydgenote. 
volkseenheid" wat een van die beweging se nasionalistiese standpunte is. 'n Amptelike gesinsbeleid is in 1942 uitgewerk wat die posisie van die Afrikaanse gesin en die Afrikanervrou in die samelewing duidelik uitgestippel het. ${ }^{2}$ P. de Klerk noem dat die OB in hulle ekonomiese en maatskaplike beleid sosialisme voorgestaan het en so ook gestreef het na 'n nuwe bedeling waar sosialisme die algemene ekonomiese stelsel sou uitmaak - vandaar die staat se rol in gesinsvorming. Die sosialisme wat die OB voorgestaan het, het egter verskil van die populêre internasionale sosialisme of kommunisme. De Klerk beskryf die OB se vorm as "volkseie of nasionale sosialisme". ${ }^{3}$ Die sosiale aspek moes hand aan hand met die nasionale een loop. So verklaar J.F.J. van Rensburg dat die OB "die volkspolitieke heil slegs [sien] in nasionalisme wat sosiaal is, en in sosialisme wat nasionaal is". ${ }^{4}$ De Klerk wys daarop dat die verband wat die OB tussen die sosiale en nasionale dimensie tref, 'n kenmerk is wat hierdie beweging by uitstek met die Europese fascistiese ideologieë deel. ${ }^{5}$ Hierdie nasionale sosialisme is in besonderhede deur die leierskap en intelligentsia van die $\mathrm{OB}$ uitgewerk en sou verreikende gevolge vir die uiteindelike hantering van gesinsvorming binne die amptelike OB-beleid hê. Die beleid het wel nie in 'n vakuum ontstaan nie. Verskeie historiese faktore het 'n rol gespeel. Vervolgens word die historiese konteks waarbinne die OB se gesinsbeleid vorm aangeneem het in oënskou geneem, waarna die amptelike gesinsbeleid teen die agtergrond van die organiese volksgedagte beoordeel word.

\section{Historiese konteks van die formulering van die Ossewa-Brandwag se gesinsbeleid}

Die OB het ontstaan en opgebloei in 'n gebeurtenisvolle tyd in die Afrikanersamelewing, 'n tyd van ongekende Afrikanernasionale opwelling en mobilisasie. D. O'Meara dui aan hoe klasalliansies in die 1930's en 1940's verskuif het namate verskillende klasse Afrikaners hulle in die kapitalistiese ekonomie geposisioneer het. ${ }^{6}$ Hy en ander navorsers het beklemtoon hoe belangrik die Afrikaner se ekonomiese volksbeweging in die 1930's en 1940's was om die opkoms van die volk se politieke mag te onderskraag. T.D. Moodie het weer aangedui hoe die Christelik-nasionale ideologie deur die Afrikaanse intellektuele elite uit 'n smeltkroes van nasionalistiese en Calvinistiese idees gevorm is. ${ }^{7}$

2. Potchefstroomkampus van die Noordwes-Universiteit, Ossewa-Brandwag Argief, (hierna OBA): J.S. de Vos-vers., B/L 1/2, omslag 1: Oorsig van die vernaamste beleidsbeginsels van die Ossewa-Brandwag; OBA: Grootraad-vers., B/L 1/4, omslag 36: Maatskaplike vraagstukke: Gesinsbeleid.

3. P. de Klerk, "Die Ideologie van die Ossewa-Brandwag”, in P.F. van der Schyff (red.), Die OB: Vuurtjie in Droë Gras (PU vir CHO, Potchefstroom, 1991), p 311.

4. J.F.J van Rensburg, Die Vooraand van Ons Volkseie Sosialisme: Die Ossewa-Brandwag Tree die Toekoms Tegemoet (Kultuur- en voorligtingsdiens van die Ossewa-Brandwag, Pretoria, 1943), p 22.

5. $\quad$ De Klerk, "Die Ideologie van die Ossewa-Brandwag, p 311.

6. D. O'Meara, Volkskapitalisme: Class, Capital and Ideology in the Development of Afrikaner Nationalism, 1934-1948 (Cambridge University Press, Cambridge, 1983).

7. T. Dunbar Moodie, The Rise of Afrikanerdom: Power, Apartheid, and the Afrikaner Civil Religion (University of California Press, Berkeley, 1975). 
Die tydperk van intense Afrikanernasionale mobilisasie in die jare tussen die wêreldoorloë het saamgeval met die opkoms van fascisme in Europese lande. Studies oor die gesinsbeleid van die Nazibewind in Duitsland beklemtoon dat Hitler en ander Nazileiers 'n organiese volksbeskouing gehad het en die skepping van 'n Volksgemeinschaft, 'n monolitiese, rassuiwere en maatskaplik heg saamgesnoerde volksgemeenskap, in die oog gehad het. Hierin moes gesinne 'n sentrale rol speel. Die meeste Nazileiers het die gesin as die kiemsel van die volk beskou. Hulle siening was dat die primêre roeping van die gesin was om deur voortplanting groot gesinne te skep waardeur die mag van die Duitse (Ariese) volk opgebou kon word. Die Naziideaal van die Ariese modelgesin was op patriargie, familialisme en die herstel van moraliteit en tradisionele gesinspatrone gebaseer. ${ }^{8}$ Onder Afrikaners het 'n paar fascisties georiënteerde kultureel-politiese organisasies tot stand gekom, waarvan die OB die grootste was.

In die tyd toe die OB op die voorgrond getree het, was verstedeliking die proses wat onteenseglik die grootste invloed op Afrikanergesinne uitgeoefen het. Navorsing vir die projek oor die Afrikaners in die Goudstad (Johannesburg) het die invloed van verstedeliking op aspekte van die Afrikaners se politieke, ekonomiese en sosiale lewe ontleed en getoon hoe die verhuising na stede tot dinamiese verandering in die verskillende aspekte van die Afrikaner se leefwêreld gelei het. ${ }^{9}$ Verskeie publikasies het nagespeur hoe die leiers van die Nasionale Party te werk gegaan het om in reaksie op die Afrikaner se tweede groot trek (die trek na die stede) die verskillende dele van die Afrikanersamelewing bymekaar te bring ter wille van Afrikanervolkseenheid. ${ }^{10}$ Die $O B$ het in dieselfde Afrikaanse dampkring van nasionalisme en republikanisme as die NP geopereer en die twee organisasies se beleidsrigtings, afgestem op 'n organiese vereniging van die Afrikanervolk, het in baie opsigte, ook gesinsbeleid, ooreengestem.

Verstedeliking het gesinspatrone in die Afrikaanse samelewing dramaties verander. Teenoor die patriargale grootgesin of uitgebreide gesin wat so kenmerkend van die sosiale organisasie op die Boereplase was, het die verstedelikte kleingesin of kerngesin te voorskyn getree. ${ }^{11}$ Afrikaanse geleerdes wat sedert die 1930's oor die situasie van gesinne geskryf het, het 'n hele rits potensiële en werklike negatiewe gevolge van verstedeliking op Afrikaanse gesinne geïdentifiseer. Daar was onder meer die moontlikheid van denasionalisering in Engelsgedomineerde stede, aftakeling van vaderlike gesag, toenemende individualisme, groter uithuisigheid van

8. M. Mouton, From Nurturing the Nation to Purifying the Volk: Weimar and Nazi Family Policy, 1918-1945 (Cambridge University Press, New York, 2009), pp 15, 17, 18; L. Pine, Nazi Family Policy, 1933-1945 (Berg, Oxford, 1997), pp 7-10, 46, 87.

9. E.L.P. Stals (red.), Afrikaners in die Goudstad, Deel 2: 1924-1961 (HAUM, Pretoria, 1986).

10. 'n Groot aantal publikasies oor hierdie onderwerp het verskyn. Vir Afrikanernasionale vertolkings, kyk onder meer D.F. Malan, Afrikaner-volkseenheid en my Ervarings op die Pad Daarheen (Nasionale Boekhandel Beperk, Kaapstad, 1959; P.W. Coetzer en J.H. le Roux (reds), Die Nasionale Party, Deel 4: Die "Gesuiwerde" Nasionale Party, 1934-1940 (INEG, Bloemfontein, 1986).

11. G. Cronjé en J.D. Venter, Die Patriargale Familie (HAUM, Kaapstad, 1973), p 121. 
gesinslede, die verswakking van familiebande, die verlies aan selfversorgendheid, 'n laer geboortesyfer per gesin, die effek van die verbruikerskultuur en toenemende materialisme, kulturele vervlakking, vroue se toetrede tot beroepsarbeid en die ondermyning van die moederskapideaal. ${ }^{12}$

Stedelike verarming was 'n ander kwelling. Toe die OB op die toneel verskyn het, was die armblankevraagstuk, wat in die vroeë twintigste eeu ernstige afmetings onder Afrikaners aangeneem het, nog nie iets van die verlede nie. Dit was juis veral verarmde Afrikaners wat 'n ekonomiese heenkome in die stede en dorpe gesoek het. Die Carnegiekommissie oor die armblankevraagstuk het bevind dat onder die ouer geslag arm Afrikaners daar nie ernstige tendense van sedelike verval te bespeur was nie. Veral die jonger geslag armes, van wie die gemiddelde opvoedingspeil laag was en wat nie oor 'n goed ontwikkelde "maatskaplike sin" beskik het nie, was egter blootgestel aan allerlei gevare wat die huwelik en gesin bedreig het, onder meer "sorgeloosheid", "karakterswakhede", egskeidings en rasvermenging. Omdat verarmde Afrikaners in baie gevalle nie voorbereid was om die veranderde eise van die tyd die hoof te bied nie, het die kommissie aanbeveel dat die regering die sosiale wetgewing moes hersien om die nuwe maatskaplike vraagstukke die hoof te bied. ${ }^{13}$

Hoewel die Carnegiekommissie nie oormatig pessimisties oor die morele peil van arm Afrikaanse gesinne was nie, was daar in Afrikaanse kerklike, akademiese en kulturele kringe kommer dat stedelike verarming tot sedelike verval en rasvermenging kon lei. Daar was in hierdie kringe sprake van 'n krisis onder Afrikaanse gesinne en die gevaar dat die verval van 'n gesonde gesinslewe die "graf van die Afrikaner se volkskultuur" kon word. ${ }^{14}$ Ernstige oproepe is gedoen dat daadwerklike stappe geneem moes word om die gesinskrisis te hanteer. J. de W. Keyter het geskryf:

Maar die innerlike betekenis soos uitgedruk in die Christelike beskouing en funksies van die huwelik en gesin en die groot uitstaande deugde van 'n huweliken gesinslewe wat deur stoere voorgeslagte aan ons geskenk is, dit kan en moet gehandhaaf word, indien die Afrikaner wil voortbestaan en sy Godgewilde nasieroeping wil vervul. ${ }^{15}$

12. J. de W. Keyter, Die Huwelik en Gesin, Tweede Trek-reeks, no. VII (Nasionale Pers, Bloemfontein, 1940), pp 99, 101, 106-107, 109-113, 115-116, 118-119, 126-127, 129, 132-137, 141; D.F. Erasmus, Die Christelike Huisgesin, Die Ossewareeks no. 3 (Pro Ecclesia-drukkery, Stellenbosch, 1942), pp 121-122. Kyk ook Cronjé en Venter, Die Patriargale Familie, pp 126-7, 130-140.

13. Die Armblanke-vraagstuk in Suid-Afrika: Verslag van die Carnegie-kommissie, Deel V: Sociologiese Verslag (Pro Ecclesia-drukkery, Stellenbosch, 1932). Inligting verkry uit die volgende afdelings van dié publikasie: "Gesamentlike bevindinge en aanbevelinge van die kommissie", p xviii, asook J.R. Albertyn, "Die Armblanke en die Maatskappy", pp 152-154, en M.E. Rothmann, “Die Moeder en Dogter van die Armgesin”, p 183.

14. Cronjé en Venter, Die Patriargale Familie, pp 140-141.

15. Keyter, Die Huwelik en Gesin, p 147. 
Blignaut \& du Pisani - Organiese nasionalisme en die amptelike gesinsbeleid van die OB

Dit is in hierdie milieu van die oortuiging in Afrikanernasionalistiese kringe dat daar 'n gesinskrisis was wat dringende optrede geverg het, dat die OB se gesinsbeleid geformuleer is.

\section{Die Afrikanerorganisme: Die gedagte aan die organiese eenheid van die volk}

Teen die agtergrond van die OB se nasionale beskouing van die "volk" moet die gesin se ideologies-geskepte en vertolkte plek gesien word binne die konteks van die OB se eiesoortige nasionaal-sosialistiese idees van nasionalisme. OB-ideologie is ook sterk gewortel in Afrikanernasionalisme se etnies-kulturele- en Christelike aspekte.

A.D. Smith identifiseer twee belangrike tipes nasionalisme. Die eerste, siviele nasionalisme, is gebou op die idee dat die nasie 'n rasionele samevoeging van burgers is, verbind deur algemene wette en 'n gedeelde grondgebied. Afrikanernasionalisme val in die kraal van die tweede tipe wat hy beskryf as 'n etniese nasionalisme "based on a belief in common culture and ethnic origins, and as such tended to regard the nation as an organic, seamless whole, transcending the individual members, and stamping them from birth with an indelible national character." 16 Bloedverwantskap en afstamming, soos later in besonderhede bespreek word, is kernelemente van die organiese element waarna Smith verwys.

H. Giliomee se beskrywing van die ideologie agter Afrikanernasionalistiese mobilisasie gedurende die dertigerjare stem ooreen met Smith se etniese nasionalisme. Afrikanerideniteit en geskiedenis is ingespan om die idee van 'n gedeelde kultuur en etniese oorsprong te skep. ${ }^{17}$ Die Afrikaner kulturele entrepreneurs, veral onder leiding van die Broederbond, het die idee van 'n eksklusiewe volk met groot sukses gepropageer. Hiervoor het kultuur 'n doel op sigself geword met nasionaliste soos D.F. Malan wat nasionale trou en kulturele trou onlosmaaklik met mekaar verbind het.18 "Nasionaliteit" word so sinoniem met "identiteit" en "etnisiteit" en is gebou op die nasionaliste se bevordering van die Afrikaner se kulturele belange en 'n spesifieke weergawe van die geskiedenis - die manifestasie van die volk se "kulturele individualiteit". ${ }^{19}$ Die gebruik van hierdie nasionalistiese konsepte het vir die Afrikaner 'n etnies-kulturele mitologie daargestel

16. A.D. Smith, Nationalism: Theory, Ideology, History (Polity Press, Cambridge, 2010), p 43. Nasionalisme is natuurlik meer kompleks as die blote verdeling daarvan in twee gerieflike digotomieë, maar hierdie verdeling is besonder van toepassing op die OB, aangesien dit juis aanvanklik uitgewerk is met die oog op die ideologieë tussen die twee wêreldoorloë en later verder konseptueel uitgebou is. Die waarde daarvan vir vandag word ook meesterlik bevestig in E. Harris, Nationalism: Theories and Cases (Edinburgh University Press, Edinburgh, 2009).

17. H. Giliomee, "The Growth of Afrikaner Identity", in W. Beinart and S. Dubow (eds), Segregation and Apartheid in Twentieth Century South Africa (Routledge, London, 1995), p 197.

18. C. Marx, Oxwagon Sentinel: Radical Afrikaner Nationalism and the History of the Ossewa-Brandwag (UNISA Press, Pretoria, 2005), p 173.

19. H. Giliomee, "The Growth of the Afrikaner's Self-concept", in H. van der Merwe, "Looking at the Afrikaner Today" (Tafelberg, Cape Town, 1975), pp 20-21 
met besondere kulturele koopkrag. ${ }^{20}$ Die idee van die "essensie" van die Afrikanervolk is aangehang ${ }^{21}$ en die mitologie wat dit onderskraag is geregverdig op religieuse wyse. Moodie het in hierdie verband die regverdiging van die kultureelmitologiese aard van Afrikanernasionalisme soos volg beskryf: "God imbues all history with ultimate meaning. God intervenes directly in history. He leads and directs people and nations, and thus their actions, past and present, are deeply imbued with a sense of salvation history." 22

Die idee dat elke volk 'n essensiële aard het, is in die kringe van Afrikanernasionaliste, wat later deel van die OB sou word, deur ' $n$ organiese metafoor beskryf. So betoog H.G. Stoker: "Die organiese eenheid van nasie spruit uit twee betreklik parallelle en samehangende wortels: (a) die vitaal organiese bloedband en (b) die geestelik-organiese kultuurband. Albei druk 'n stempel op die individu af, waardeur die volksgeheel tiepiese eieaard verkry [sic]."23 Hand aan hand met hierdie idees het Christelike nasionalisme geloop.

Afrikanernasionalisme se Christelike elemente is nie net gebaseer op die bogenoemde beskrywing van Moodie nie, maar ook op die voorveronderstelling dat God diversiteit in die skepping waardeer. Net soos daar ' $n$ wye verskeidenheid in die natuur is, so bestaan daar ook 'n groot verskeidenheid volke. Christelike nasionalisme stel die diversiteit van onderskeie volke gelyk aan nasieskap, aangesien God se wil geïnterpreteer word as die begeerte om verskillende mense te skep wat uit verskillende nasies bestaan. ${ }^{24}$ Dit is ook God-gegewe dat jy aan 'n spesifieke nasie of volk behoort, en dus jou aktief by hulle moet skaar as deel van God se plan. Dit beteken ook die verwerping van beide kultuur- en rassevermenging, omrede: "Verskeidenheid is lewe. Maar by alle verskeidenheid moet daar suiwerheid van tipe wees." 25 Hierdie Christelike regverdiging vir nasionalisme kom ook duidelik na vore in die volgende woorde van Stoker: "Omdat ons Christene is, is ons ook nasionaal. Ons is nasionaal omdat ons dit wat ons eie is liefhet en respekteer. Ons is nasionaal omdat alles wat ons is God se wil is en deur God geskep is."26

Die OB het die organiese volksgedagte as baie belangrik beskou en het dit baseer op etnies-kulturele- en Christelike nasionalisme. Afrikanerdenkers het 'n sterk invloed uitgeoefen op spesifiek die OB se organiese nasionalisme. Hierdie idee sou uiteindelik die beweging se latere gesinsbeleid sterk beïnvloed.

20. Sien in hierdie verband L. Thompson, The Political Mythology of Apartheid (Yale University Press, New Haven, 1985).

21. Marx, Oxwagon Sentinel, p 174.

22. Moodie, The Rise of Afrikanerdom, pp 1, 11.

23. H.G. Stoker, "Die Idee van Nasionalisme", Tydskrif vir Wetenskap en Kuns, 10 (1931), pp 51-58.

24. Marx, Oxwagon Sentinel, p 191.

25. D.N. Kotzé, “Die Christen en sy Vaderland”, Koers, 2, 6 (1935), pp 24, 26.

26. Die Volksblad, 1 November 1947. 
Afrikanernasionalisme het ontwikkel in 'n soort nasionalisme waar meer waarde geheg is aan die kollektiwiteit van die nasie as om die individu voorop te stel. ${ }^{27}$ Organiese nasionalisme is deur sommige lede van die Afrikaner-intelligentsia tot 'n omvattende beskouing omskep. Dié beskouing is veral te bespeur in die studie van N. Diederichs. In 1936 het hy sy belangrikste werk oor nasionalisme gepubliseer: Nasionalisme as Lewensbeskouing en sy Verhouding tot Internasionalisme. Marx verwys na hierdie werk as "doubtless one of the most ambitious attempts ever to give nationalism a philosophical grounding". ${ }^{28}$

In hierdie werk groepeer Diederichs die verskillende werklikheidsvisies wat in die 1930's 'n invloed op die politiek uitgeoefen het. Hy verwerp kommunisme en liberalisme as ideologieë wat materialisme as basis gekies het. Beide hierdie ideologieë lei tot 'n beskouing dat die ganse mensdom uit geïsoleerde individue bestaan. ${ }^{29}$ Diederichs sien nasionalisme as alternatiewe opsie, aangesien nasionalisme gebou is op die idee dat die mens 'n sosiale wese is wat geroep is om in 'n gemeenskap te leef:

Die individu of enkelmens as sodanig is 'n abstraksie wat nie bestaan nie. Buite die gemeenskap en die verkeer met ander menslike wesens is die mens geen volwerklike mens nie. As van nature sosiale wese, word en is hy eers mens in die volle sin van die woord binne die menslike gemeenskap. ${ }^{30}$

Diederichs gebruik daarop 'n organiese metafoor om sy idee by die leser in te prent: "Net soos die blaar nie buite die tak en die tak nie buite die boom kan bestaan as blaar of as tak nie, net so min kan die mens werklik mens wees sonder die lewende verbinding en verkeer met ander mense." 31 Voorts is die mens nie net sosiale wese nie, maar ook nasionale wese, aangesien die mens sonder "die opheffende, veredelende en verrykende invloed van hierdie hoogste omvattende eenheid wat ons nasie noem... nooit die volle hoogte van menswees bereik nie". ${ }^{32}$ Diederichs beskou die nasie as kulturele gemeenskap wat bokant die politieke arena uitstyg.

27. P. de Klerk, "Afrikanerdenkers en die Beginsels van die Ossewa-Brandwag", Joernaal vir Eietydse Geskiedenis, 14, 1 (1989), p 44. Verskeie skrywers oor die OB dui daarop dat die Afrikanerdenkers beïnvloed was deur sogenaamde "neo-Fichteaanse nasionalisme". C. Marx het egter hewige kritiek hierop gelewer (sien Marx, Oxwagon Sentinel, pp 220-227) en om daardie rede word die term hier vermy. Die Duitse invloed op die denkers van die OB is 'n studie op sigself en daarom fokus die huidige studie op die invloed van Afrikanerdenkers se eie idees oor OB-beleid, soos in hulle eie publikasies vervat.

28. Marx, Oxwagon Sentinel, p 213.

29. Marx, Oxwagon Sentinel, p 214.

30. N. Diederichs, Nasionalisme as Lewensbeskouing en sy Verhouding tot Internasionalisme (Nasionale Pers, Bloemfontein, 1936), p 17.

31. Diederichs, Nasionalisme as Lewensbeskouing en sy Verhouding tot Internasionalisme, p 17.

32. Diederichs, Nasionalisme as Lewensbeskouing en sy Verhouding tot Internasionalisme, p 31 . 
Die OB het egter nie Diederichs se idealisme in hierdie verband in die geheel aanvaar nie. Hulle het bloedverwantskap en afstamming beskou as kernaspekte wat individue tot 'n nasie laat behoort. Diederichs het aan die ander kant geglo "[o]m bloedverwantskap of afstamming tot toets van nasieskap te maak, sou beteken om alles wat skoon, hoog en edel in die nasie is, te verraai". ${ }^{33}$ Diederichs het wel OBbeleid beïnvloed deur sy beskouing van die mens as nasionale wese, as integrale, organiese deel van mekaar. Die organiese aspek verwys hier na die onlosmaaklike sosiale band.

Diederichs het nooit enige posisie in die OB beklee nie. Tog het sy idees veral deur sy volgeling en student, P.J. Meyer, in OB-beleid neerslag gevind. Meyer was Voorligtingshoof in die $\mathrm{OB}$ en het ook op die Grootraad gedien. Hy het later indringend aandag gegee aan die organiese idees wat deur Diederichs se nasionalisme voorgehou word. So beskou Meyer ook die nasie (hy verkies die woord "volk") as die omvattendste werklikheid van die mens: "Buite hierdie organiese eenheid kan geen Afrikaner as Afrikaner bestaan nie."34 Meyer het die OB gesien as 'n beweging wat só 'n soort eenheid kon bewerkstellig. Die Afrikaanse volksbeweging wat ná 1938 tot stand gekom het, moes "'n strawwe, dissiplinerende organisasie [wees], waarin verantwoordelike volksleiding en aktiewe volksmedewerking as eenheidsgesagsverband omvat word". 35

De Klerk wys daarop dat Meyer se beskouing van die organisasie van die volksbeweging (al die Afrikanernasionalistiese organisasies regoor verskillende sektors) saamhang met sy konsep van die volk se organiese verband: "Die volk is vir hom 'n selfstandige skeppingskring wat wel met ander kringe ineengevleg is, maar tog 'n eie onvernietigbare kern het."36 In sy werk, Die Vooraand van ons Vrywording beskryf Meyer die volk as 'n organiese gemeenskap; as

piramidale ordening van volksgebonde enkelinge met leiers wat op natuurlike wyse daardie plek op grond van hul besondere gawes en daadkrag verwerf. $0 p$ dieselfde wyse verower al die volkslede binne hierdie natuurlike orde eie en onvervangbare plek op grond van hul besondere talente en arbeid. ${ }^{37}$

De Klerk dui aan dat Meyer ook in die volksbeweging as sodanig wil sien dat daar só 'n organiese verhouding tussen leiers en volgelinge gestalte kry. ${ }^{38}$ Meyer beskou die volksbeweging as "die motor wat die staatsmasjinerie in beweging hou en wat die staat in sy wetgewing en instellings voed vanuit die gehele volkslewe". 39 Sy mening

33. Diederichs, Nasionalisme as Lewensbeskouing en sy Verhouding tot Internasionalisme, pp 31-32.

34. P.J. Meyer, Die Vooraand van Ons Vrywording: Die Afrikanerdom Één en Verdeeld (ANJ, Kaapstad, 1941), p 19.

35. P.J. Meyer, Die Toekomstige Ordening van die Volksbeweging in Suid-Afrika (Pro Ecclesia, Stellenbosch, 1942), p 10.

36. De Klerk, "Afrikanerdenkers en die Beginsels van die Ossewa-Brandwag", p 77.

37. Meyer, Die Vooraand van Ons Vrywording: Die Afrikanerdom Één en Verdeeld, p. 19.

38. De Klerk, "Afrikanerdenkers en die Beginsels van die Ossewa-Brandwag", p 78.

39. Meyer, Die Toekomstige Ordening van die Volksbeweging in Suid-Afrika, p 22. 
Blignaut \& du Pisani - Organiese nasionalisme en die amptelike gesinsbeleid van die OB

dat elke lid van die volk op grond van sy/haar "besondere gawes en daadkrag" 'n besondere plek in die organiese volkseenheid het, het later die posisie van die gesin direk geraak. ${ }^{40}$

De Klerk noem dat daar hoofsaaklik twee denkrigtings was wat OB-beleid sou beïnvloed. ${ }^{41}$ Aan die een kant sou die Calvinisme van Stoker en L.J. du Plessis OBbeleid raak; aan die ander kant sou die idealisme van Diederichs nóu aansluit by Meyer wat hierdie idees in OB-beleid sou laat geld. Albei denkstromings sou in die OB geïntegreer word deur die konsep "die organiese eenheid van die volk". 42 Volgens dié konsep word die geheel groter beskou as die dele, maar waarbinne elke deel 'n eie, spesifieke "plek" in die geheel het om te vervul. Nie net die idealistiese denke van Diederichs en Meyer het die plek van die OB-gesin bepaal nie. Die Calvinisme van Stoker het ook later in die OB se beleid oor die gesin neerslag gevind.

Tydens die beginjare van die OB het Stoker die amp van hoofkommandant beklee. Tussen 1942 tot 1943 is hy nege maande lank deur die regering geïnterneer, aangesien hy volgens De Klerk beskou is as "belangrike intellektuele leier van die versetbeweging teen die Suid-Afrikaanse oorlogsdeelname". ${ }^{33}$ Stoker het in later jare 'n raadgewende rol in die OB gespeel. Sy sleutelwerk, Die Stryd om die Ordes (1941), is deur dr. J.F.J. van Rensburg bestempel as leidraad vir die OB op ideologiese gebied. ${ }^{4}$ In hierdie werk dui hy die verhouding tussen die heersende ideologieë van die tyd aan: liberalisme, kommunisme, Nasionaal-Sosialisme, Fascisme en Calvinisme. De Klerk som Stoker se beoordeling van elke stelsel soos volg op:

Stoker toon aan dat in elke stelsel of ideologie 'n bepaalde faset van die werklikheid verabsoluteer word, naamlik in die Liberalisme die "soewereine redelik-sedelike individu", in die Kommunisme "die werkersklas wat ekonomiese goedere, ekonomies-stoflike welvaart voortbring en onder ekonomiese wette staan", en in die Nasionaal-Sosialisme die "deur bloed en bodem bepaalde volk". Daarteenoor stel die Calvinis alleen God as absoluut. ${ }^{45}$

In teenstelling met Diederichs, beskou Stoker nie een menslike verband, soos die staat of volk, as geheelverband waarin ander verbande opgaan nie. Deur Stoker se gebruik van die leer van soewereiniteit in eie kring begin sy organiese geheelbeeld na vore kom. ${ }^{46}$ Stoker betoog: "Die menslike verband (staat, volk, gesin, maatskappy, ens.) is nie kollektiwiteit, blote versameling nie, maar het eie struktuur, eie taak en

40. De Klerk, “Afrikanerdenkers en die Beginsels van die Ossewa-Brandwag”, p 78.

41. De Klerk, "Afrikanerdenkers en die Beginsels van die Ossewa-Brandwag", p 77.

42. Hier word hoofsaaklik gefokus op denkers se idees van "organiese eenheid" wat later die OB se beleid oor die gesin geraak het. Vir 'n uiteensetting van L.J. du Plessis se invloed, sien Marx, Oxwagon Sentinel, pp 500-503.

43. De Klerk, “Afrikanerdenkers en die Beginsels van die Ossewa-Brandwag", pp 56-57.

44. OBA, Die $O B, 15$ April 1942.

45. De Klerk, "Afrikanerdenkers en die Beginsels van die Ossewa-Brandwag", p 59.

46. R.A. Clouser, The Myth of Religious Neutrality (University of Notre Dame Press, Notre Dame, 2005), pp 290-302. 
bestemming, wat dit nie van individue nie, maar van God ontvang het." 47 Dit beteken egter nie dat die verbande elkeen afsonderlik funksioneer nie, die verbande werk saam in 'n "organiese eenheid". Hy wys daarop:

... dat hierdie menslike verbande nie los langsmekaar, nie van mekaar geïsoleerd bestaan nie, maar onderling vervleg is, in elke individu mekaar kruis, op mekaar aangewys is, van mekaar afhanklik is, mekaar aanvul en dat hulle dus onderling behoort te harmonieer, saam te werk en onderlinge, vrye wisselwerking behoort te verseker, sonder dat die een die ander oorheers; sodat elkeen en almal saam aan hul doel beantwoord, wat uiteindelik gelyk staan met die eer en verheerliking van God; dat ook hier onderskeid en samehang erken moet word. ${ }^{48}$

Stoker sien dus 'n verbintenis tussen die onderskeie lewensverbande. Wat die samelewingsverband van die volk betref, is dit geen "optelsom van individue nie, maar organiese eenheid". ${ }^{49}$ Stoker gaan so ver as om die volk 'n organisme te noem: "Die volk is organisme... want die mens is nie net individu nie. Hy is ook volksgenoot. Sy volk is organiese eenheid. Bowendien gee God aan elke volk, ook aan ons Afrikanervolk, eie aard, eie taak, eie bestemming en eie roeping, wat ons alleen as volk, in organiese volksverbondenheid kan vervul." 50 Stoker verduidelik verder dat die aard van die volk deur vier beginsels bepaal word. Hy noem dit die organiese bloedband, die organiese kultuurband, die landsband en die historiese band. Elke volksgenoot maak 'n organiese deel van die volk uit en kan slegs lid van 'n ander volk word deur 'n organiese groeiproses waarby daardie lid deur die organiese kultuurband, en later sy/haar nageslag ook deur die bloedband ingelyf word. ${ }^{51}$

Stoker se gebruik van die woord "organies" is veelseggend. Die beskrywing van die Afrikanervolk as organisme is nie heeltemal versoenbaar met soewereiniteit in eie kring nie, aangesien dit die biotiese verband (modaliteit) van die werklikheid bó ander verbande plaas. Hierdie spanning kan 'n mens regdeur Die Stryd om die Ordes bespeur en getuig van Stoker se nasionalisme wat wel gebruik maak van die organiese metafoor, maar deur Calvinisme getemper. Die rede is dat hierdie siening nie die organiese dimensie, soos in die geval van Diederichs se "nasie", as die geheelverband van die samelewing benader nie. Ten spyte van Stoker se aanspraak dat sy siening soewereiniteit in eie kring eerbiedig, is daar wel ook 'n ooreenstemming tussen hom en Diederichs deurdat hy individuele volksgenote sien as deel van 'n oorkoepelende "Afrikanerorganisme".

Vir elke sfeer om egter soewerein te bly, moet dit slegs aan God verantwoording doen. Stoker verwerp ook die idealisme van Diederichs deur die geestelike as aards te beskou - as skepping van God en nie as sodanig goddelik nie. ${ }^{52}$ Anders as Diederichs beskou Stoker die mens ook nie bloot as sosiale wese nie. Hy

47. H.G. Stoker, Die Stryd om die Ordes (Calvyn-Jubileumboekefonds, Pretoria, 1941), p 56.

48. Stoker, Die Stryd om die Ordes, $\mathrm{p} 13$.

49. Stoker, Die Stryd om die Ordes, p 83.

50. Stoker, Die Stryd om die Ordes, p 83.

51. De Klerk, "Afrikanerdenkers en die Beginsels van die Ossewa-Brandwag", p 60.

52. Die Volksblad, 25 April 1936. 
Blignaut \& du Pisani - Organiese nasionalisme en die amptelike gesinsbeleid van die OB

meen dat "die mens tegelyk individuele en sosiale wese is, tegelyk individu en bv. volksgenoot, kerklidmaat, staatsburger, gesinslid, ens.".53 Dit wil voorkom of Stoker die samelewing beskryf as organisme om juis daardeur op 'n unieke manier die idee van soewereiniteit in eie kring te verduidelik. Stoker se Afrikanerorganisme bestaan uit samelewingsverbande wat soewerein in eie kring is, maar gelyk ook soewerein tot en interafhanklik van mekaar. Ten spyte van Stoker se kritiek teen Diederichs se metafisiese voorveronderstellings, het laasgenoemde se idees vir Afrikanernasionaliste 'n praktiese doel gedien. Hier was Diederichs se "verabsolutering" van die volksverband veral aantreklik vir die nasionaal-sosialistiese tendense in die OB asook vir die politieke stryd van die Afrikanernasionaliste.

Volksverband is dus geabstraheer tot iets waarin alle ander samelewingsverbande opgaan. Daarby het die beskouing gegeld van die mens as hoofsaaklik sosiale wese. Beide sienings sou deurentyd in konflik met die Calvinistiese beginsel van soewereiniteit in eie kring kom. Tog sou die middeweg die genoemde interne spanning in die idees van Stoker wees wat aan die een kant die mens as beide sosiaal en individueel sien, die volks- of nasieverband aan ander samelewingsverbande gelykstel, en tog erken dat die Afrikanervolk as organisme optree. Hierdie konflik het ook later in OB-beleid kop uitgesteek.

\section{Die Afrikanerorganisme en die ideaal van 'n nuwe samelewingsorde: Die OB se verstaan van die Afrikanervolk se organiese eenheid}

Organiese nasionalisme het tydgenote se idees oor die gesin beïnvloed. Om laasgenoemde invloed te bepaal, is dit egter nodig om te verstaan watter aspekte van OB-ideologie uitvoering gegee het aan die organiese idees van die genoemde Afrikanerdenkers.

Die OB het die organiese verstaan van die volk deeglik belig deur dit op biologiese grondslag te verduidelik waar die geheel (die volk) groter is as die dele (individuele volksgenote): "'n Organiese iets is 'n wese wat lewe en groei, wat 'n saamgestelde geheel is en samestellende dele of lede (organe) het wat deur die geheel beheers word en wat op hulle beurt mekaar aanvul en die geheel dien. Dit is dus 'n soort lewende liggaam." 54 Gevolglik word die volksverband bó die ander samelewingsverbande geplaas, maar word daar tog ook heel teenstrydig gehoor gegee aan die leer van soewereiniteit in eie kring:

[D]ie organiese eenheid van 'n groep soos 'n volk [is] ook 'n geestelike eenheid: dit vorm nie ' $n$ werklike sigbare en tasbare liggaam waarvan die lede nie buite die liggaam kan bestaan nie. Nee, dit is ' $n$ geestelike eenheid, ' $n$ eenheid van saamhorigheid, waarvan die lede ook in ander selfstandige eenhede verbind kan wees. Die eenheid van 'n volk beheers dus nie die enkele persone en groepe wat daarin ingesluit is, volledig nie, maar beheers hulle net vir die doeleindes van die

53. Stoker, Die Stryd om die Ordes, p 13.

54. OBA: D.J.M. Cronjé-vers., B/L 1/5, omslag 4: Die Ossewa-Brandwag: Vanwaar en Waarheen?, p 27. 
bepaalde bestemming van die volkslewe as geheel. En daarnaas behou hulle nog elkeen hulle eie bestemming en hulle selfstandigheid ook in die verwesenliking van daardie bestemming. 55

Die bostaande uiteensetting toon die duidelike teenstrydigheid wat ook in Stoker se organiese nasionalisme skuil. Aan die een kant word die volk nie beskou as 'n geheelverband wat die enkelinge en groepe wat lid daarvan is volledig omvat nie ("die eenheid van ' $n$ volk beheers dus nie die enkele persone en groepe wat daarin ingesluit is, volledig nie..."). Dit stem uiteraard ooreen met die Calvinistiese idee van soewereiniteit in eie kring ("elkeen [behou] hulle eie bestemming en hulle selfstandigheid ook in die verwesenliking van daardie bestemming"). Aan die ander kant word die leuse "volksbelang voor eiebelang"56 dikwels gebruik en geld die voorrang van die volk bó die van die individu: "[D]ie enkeling [kan] nie maar eiewillig doen en laat wat hy wil nie, maar hy moet sy lewe in diens stel ook van sy volk en sy volksgenoot; hiervolgens kan ook enige groep in die volk nie slegs sy eie belang en voordeel nastrewe nie, maar moet elke groep sy eie aandeel bydra tot die welsyn van ander en van die geheel."57 Die teenstrydigheid lê in die invloed van Stoker se Calvinisme, die idealistiese beskouing van Diederichs en Meyer op die OB-ideologie asook die aantrekkingskrag van Nasionaal-Sosialisme. Nêrens spreek die OB-denkers hulle in amptelike stukke verder oor hierdie probleem uit nie en word sodanige eiesoortige organiese nasionalisme vanselfsprekend as deel van OB-beleid voorgehou. 58

Diederichs se totalisering van die "nasie" het die praktiese doelwitte van Afrikanernasionaliste in die latere Broederbond gedien. ${ }^{59}$ In dieselfde sin het die organiese nasionalisme van die OB (ongeag die teenstrydighede) as motivering en regverdiging gedien vir die daarstel van 'n gesagstaat wat aan alle samelewingsverbande 'n gemeenskaplike doel gee. Dit het ook gegeld vir daardie verbande waarin vroue en die gesin later in die OB kon funksioneer. Die gesagstaat wat die OB in die vooruitsig gestel het, is ook 'n "organiese gesagstaat" genoem. Die Ossewa-Brandwag: Vanwaar en Waarheen? onderskei tussen die "suiwere magstaat", die "liberalistiese wetstaat" en die "organiese gesagstaat". Die liberalistiese wetstaat word beskou as "na sy wese niks anders as 'n verswakte magstaat nie", aangesien die mag van die staat in wetgewende, regterlike en uitvoerende mag verdeel is. As alternatief word die organiese gesagstaat of volkstaat voorgehou. ${ }^{60}$ De Klerk wys

55. OBA: D.J.M. Cronjé-vers., B/L 1/5, omslag 4: Die Ossewa-Brandwag: Vanwaar en Waarheen?, p 28.

56. OBA: D.J.M. Cronjé-vers., B/L 1/5, omslag 4: Die Ossewa-Brandwag: Vanwaar en Waarheen?, p 6.

57. OBA: D.J.M. Cronjé-vers., B/L 1/5, omslag 4: Die Ossewa-Brandwag: Vanwaar en Waarheen?, pp 29-30.

58. De Klerk, "Afrikanerdenkers en die Beginsels van die Ossewa-Brandwag”, p 97.

59. Moodie, The Rise of Afrikanerdom, $\mathrm{p} 161$.

60. OBA: D.J.M. Cronjé-vers., B/L 1/5, omslag 4: Die Ossewa-Brandwag: Vanwaar en Waarheen?, p 52. 
Blignaut \& du Pisani - Organiese nasionalisme en die amptelike gesinsbeleid van die OB

daarop dat hierdie soort staat as staatsvorm van die toekoms beskou is. ${ }^{61}$ So 'n staat word deur die volksbeweging daargestel, tree in die belang van die volk op en geniet dus ook die volk se vertroue. Die organiese gesagstaat is gesien as deel van 'n nuwe wêreldbeweging waarvan die OB in Suid-Afrika die uitdrukking wou wees en poog om hierdie samelewingsideaal te bereik:

Die nuwe wêreldbeweging wat op 'n algehele omwenteling in alle lande uitloop, het ook in Suid-Afrika met die Ossewatrek ontstaan en die behoefte aan, ja, die noodsaaklikheid van 'n omvattende volksorganisasie, wat meer as 'n party sou wees, is geopenbaar in die aanvaarding van die Ossewa-Brandwag deur die volk as die organisasie wat die leiding van die omwenteling in ons volksgees moet gee en moet uitloop op die nuwe, organiese solidarisme. Hierdie ontwikkeling het die Ossewa-Brandwag tot 'n algemene volksbeweging gemaak. ${ }^{62}$

Dit kom neer op die OB se ideologie wat 'n eskatologiese fokus het. Met ander woorde, die $O B$ wou hulle ideologie inspan vir die bogenoemde samelewingsideaal van 'n Afrikaanse gesagstaat wat as algehele einddoel alle samelewingsverbande in diens van die volk wou inspan. Die gesagstaat sou vir elke individu wat deel van die geheel uitmaak 'n doel gee wat met die organiese eenheid van die volk ooreenstem:

So alleen sal ons nasionale lewe eindelik weer word, soos God dit bedoel het om te wees, 'n samelewing volgens vaste plan op 'n vaste doel af, waarin elke lid en deel sy heil daarin sal vind dat hy volgens eie aard sy eie bestemming verwesenlik, maar ook sy bepaalde deel bydra tot die welsyn van al die ander en van die geheel. Dit is wat die Ossewa-Brandwag bedoel met die begrip van die Organiese Afrikanerdom. ${ }^{63}$

Die gesin is uiteraard ook een van die individuele dele van die Afrikanerorganisme waaraan 'n spesifieke plek, met'n spesifieke doel, toegeskryf is as deel van die OB se samelewingsideaal. Dit het hoofsaaklik gefokus op die vrou se plek in die gesin wat gesien is as "die grondslag van die volk". ${ }^{64}$ Deur haar plek in die gesin kon die vrou binne die OB haar eie doel soewerein en in eie kring nakom, maar terselfdertyd ook deur die gesin die geheel dien in ooreenstemming met die organiese "volkskonsep" van die OB. Die OB se gesinsbeleid het regstreeks uit die organiese verstaan van die volk voortgevloei.

61. P. de Klerk, "Die Ossewa-Brandwag se Ideaal van 'n Nuwe Samelewingsorde in SuidAfrika”, Joernaal vir Eietydse Geskiedenis, 14, 2 (1989), pp 90-131.

62. A.J.H. van der Walt, 'n Volk op Trek: 'n Kort Geskiedenis van die Ontstaan en Ontwikkeling van die Ossewa-Brandwag (Kultuur- en Voorligtingsdiens van die Ossewa-Brandwag, Johannesburg, 1941), p 121.

63. OBA: D.J.M. Cronjé-vers., B/L 1/5, omslag 4: Die Ossewa-Brandwag: Vanwaar en Waarheen?, p 30.

64. OBA: D.J.M. Cronjé-vers., B/L 1/5, omslag 4: Die Ossewa-Brandwag: Vanwaar en Waarheen?, p 26. 
Blignaut \& du Pisani - Organiese nasionalisme en die amptelike gesinsbeleid van die OB

\section{Die kern van die Afrikanerorganisme: Die Ossewa-Brandwag se amptelike gesinsbeleid}

Die sosialisme wat die OB op grondslag van nasionalisme nagestreef het, word vervat in die beweging se maatskaplike beleid waarvan die gesinsbeleid ' $n$ uitvloeisel is. Sedert die stigting van eersgenoemde beleid was die OB se doelstelling om die Afrikaner maatskaplik en ekonomies op te hef.65 In Oktober 1942 het die OB se leierskap hulle amptelike gesinsbeleid bekendgestel in 'n publikasie met die naam "Gesonde Huisgesinne Bou 'n Lewenskragtige Volk". ${ }^{66}$ Teen 1943 is die vernaamste beleidsbeginsels van die OB uitgewerk en het dit die gesinsbeleid ingesluit. ${ }^{67}$ In 1949 is die gesinsbeleid opnuut gepubliseer in 'n reeks artikels in Die OB.68 In die OB se maatskaplike en volksbeskouing staan die gesin sentraal en word die rol van die Afrikanervrou as deel van die Afrikanerorganisme duidelik omskryf.

OB-leierskap het die organisasie gesien as die "herskepper van die organiese Afrikanerdom". ${ }^{69}$ Die OB het die Afrikanergesin as die beginpunt van die herskepping van die samelewing en die inlei van 'n nuwe samelewingsorde gesien: "Daarom beklemtoon die volksbeweging dat vir die volksherskepping allereers die huisgesin herskep moet word sodat dit selfstandig kan wees, 'n menswaardige welstandpeil kan bereik en handhaaf en die organiese volksgeheel in stoflike en geestelike opsig kan bewaar". ${ }^{70}$ Die klem op die gesin as punt van oorsprong vir die hervorming van die samelewing stem ooreen met die organiese nasionalisme van die OB. Hiervolgens is die belangrikheid van die gesin dwarsdeur die OB-beleid sterk benadruk. So is bepaal dat "die eenheid en hoeksteen van die Volk" die huisgesin behels. ${ }^{71}$ In Die OB-koerant is verklaar: "Vir die Ossewabrandwag as 'n uitgroeiing van die volksgedagte is die gesinslewe in die volk van besondere belang omdat die gesinslewe die vernaamste grondslag vorm van die volksbestaan".72 In die amptelike beleidsdokument wat die Grootraad goedgekeur het, word 'n gesin beskryf as "in 'n sekere sin die volk in die klein".73 Vir die beweging se klem op die gesin het die OB in die geskiedenis van die Afrikaner 'n regverdiging gekry:

Nie die enkeling nie, maar die Afrikaanse gesin was die baanbreker van ons land.

Die Afrikaanse gesin het die stryd van Slagtersnek gevoer. Dit was die Afrikaanse

65. Van der Walt, 'n Volk op Trek, pp 11-13.

66. Grootraad van die Ossewa-Brandwag, Gesonde Huisgesinne Bou 'n Lewenskragtige Volk (Pro-Ecclesia, Stellenbosch, 1942).

67. OBA: J.S. de Vos-vers., B/L 1/2, omslag 1: Oorsig van die Vernaamste Beleidsbeginsels van die Ossewa-Brandwag.

68. OBA: Die OB, 9 Februarie 1949, 16 Februarie 1949, 16 Maart 1949, 23 Maart 1949, 30 Maart 1949 en 13 April 1949.

69. OBA: D.J.M. Cronjé-vers., B/L 1/5, omslag 4: Die Ossewa-Brandwag: Vanwaar en Waarheen?, p 24.

70. OBA: D.J.M. Cronjé-vers., B/L 1/5, omslag 4: Die Ossewa-Brandwag: Vanwaar en Waarheen?, p 26.

71. OBA: Grootraad-vers., B/L 1/4, omslag 36: Die Sedelike Grondslag van die OB-familie.

72. OBA, Die $O B, 12$ Julie 1948.

73. OBA: Grootraad-vers., B/L 1/4, omslag 36: Maatskaplike Vraagstukke: Gesinsbeleid. 
gesin wat getrek en die Republieke in die Noorde gestig het. Die Afrikaanse gesin het die Tweede Vryheidsoorlog gevoer en dit is die Afrikaanse gesin wat vandag veg vir die vryheid en eenheid van die Afrikanerdom. ${ }^{74}$

Die gesin het dus 'n sentrale plek binne die ideologie en toekomsvisie van die OB beklee. Die rede is dat die gesin beskou is as die beginpunt van die Afrikanervolk in die verlede sowel as die beginpunt vir die hervorming van die Afrikanersamelewing in die toekoms.

Die organiese nasionalisme van die OB gaan nóú met die gesinsbeleid gepaard. Die gesin is die "elementêrste lewensvorm" van die volk en dra al die eienskappe daarvan in die kleine. Daar is sover gegaan as om te sê "[d]ie Afrikanerdom is een groot gesin". ${ }^{75}$ Die gesin is ook 'n middel vir die OB om volksbelang bó eiebelang te plaas. Die OB het groter klem op die gesinne as op enkelinge laat val. ${ }^{76}$ Gevolglik kon die beweging volhou dat "die belange van die gesinsgeheel swaarder weeg as die belange van die gesinslid, terwyl die belange van die volksgeheel swaarder weeg as die belange van elke besondere gesin". ${ }^{77}$ Die organiese nasionalisme binne hierdie aanhaling word verder benadruk deur biologiese metafore om die gesin te beskryf: "Hoewel in sy wese meer as ' $n$ blote sel, verteenwoordig die huisgesin in die bloedgemeenskap van die organiese volk 'n lewensel". ${ }^{78}$ Die gesin moet dus die verskillende gesinsfunksies in diens van die volk beoefen. ${ }^{79}$

Die gesinsbeleid en die funksies wat die OB vir die gesin uiteengesit het, was ' $\mathrm{n}$ reaksie op die vinnig veranderende Afrikanersamelewing wat aangehelp is deur verstedeliking en die verarming van die Afrikaner. Hierdie faktore het gelei tot ' $n$ gesinskrisis terwyl die "liberalistiese lewensbeskouing", met die klem op die individu in plaas van die gemeenskap bygedra het tot "die ontbinding van die gesin". Dit was die OB se motivering hoekom die volk herskep moes word deur ontslae te raak van die "huidige dobbelgebou" waarin die Afrikaner vasgevang was en dit te vervang met "'n gemeenskaplike volksgebou op die Nasionale en sosiale fondamente van die Christelike lewensbeskouing". ${ }^{80}$

Met die oog op so 'n herskepping moes daar dus, volgens die plek van die gesin as kern van die Afrikanerorganisme, allereers begin word om die gesin nuut te skep: "Om te begin moet ons die gesinslewe van die volk op 'n heeltemal nuwe grondslag plaas en hervorm". ${ }^{81}$ So het die OB dit in die vooruitsig gestel dat die gesin sodanig

74. OBA: Die $O B, 20$ Mei 1942.

75. OBA: Die $O B, 20$ Mei 1942.

76. OBA: Die $O B, 21$ Junie 1948.

77. OBA: Grootraad-vers., B/L 1/4, omslag 36: Maatskaplike Vraagstukke: Gesinsbeleid.

78. OBA: D.J.M. Cronjé-vers., B/L 1/5, omslag 4: Die Ossewa-Brandwag: Vanwaar en Waarheen?, p 26.

79. Grootraad van die Ossewa-Brandwag, Gesonde Huisgesinne Bou 'n Lewenskragtige Volk, p 5.

80. Grootraad van die Ossewa-Brandwag, Gesonde Huisgesinne Bou 'n Lewenskragtige Volk, p 26.

81. OBA: Die OB, 21 Junie 1948. 
herskep word dat dit selfstandig is en 'n menswaardige welvaartspeil sou kon bereik en handhaaf. Die OB se amptelike beleid het die verband tussen die volk en die gesin se selfstandigheid getref. $820 \mathrm{~m}$ hierdie selfstandigheid te bereik, moes die staat 'n uiters belangrike rol speel. Hierdie rol het die volgende maatreëls ingesluit:

- die verskaffing van huweliksvoorskotte wat jong getroude paartjies in staat gestel het om selfversorgend te raak; ${ }^{83}$

- rentelose lenings waarvan 'n kwart by die geboorte van tot vier kinders afgeskryf word; 84 en

- die hersiening van mense se inkomstepeil met die oog daarop om "die uiterste lae inkomstepeil en die uiterste hoë inkomstepeil nader aan die menswaardige gemiddelde te bring". 85

Verskeie ander voorbeelde wat met "die organiese volksbegrip" ooreenstem, is deur die OB-leierskap voorgehou, onder meer die nasionalisering van alle eiendom in diens van die "volkshuishouding". ${ }^{86}$ Verder het die gesin ook sekere funksies vervul waarin die vrou 'n onmisbare rol gespeel het - in so 'n mate dat die gesinsbeleid waardeloos beskou is sonder die aktiewe deelname van die Afrikanervrou. So is daar verklaar dat die Ossewa-Brandwag die volgende wil doen:

[D]eur intensiewe organisasie, gebaseer op die kommando-stelsel, [vir] elke man en vrou soos 'n skakel in 'n ketting 'n plek gee vir die doeltreffende uitvoering van sy taak van inskerping en handhawing van 'n hoë standaard van eer en plig teenoor ons land, volk en ons kerk, met insluiting van die openbare as die persoonlike en gesinslewe. ${ }^{87}$

Die onderskeid tussen die "openbare" en die "persoonlike en gesinslewe" binne die $\mathrm{OB}$ is veelseggend. Volgens hierdie onderskeid is aan elke man en vrou "' $\mathrm{n}$ plek" gegee. In die gesin het elke lid - manne sowel as vroue - 'n besondere taak vervul:

Die taak van die man is geleë in die behartiging van die beroepsarbeid, die volkspolitiek en die krygskuns, terwyl die taak van die vrou in die gesinshouding en die volksversorging geleë is - sy is die spil waarom die gesinsvorming, die gesinsopvoeding en volksorg, draai. ${ }^{88}$

82. OBA: Grootraad-vers., B/L 1/4, omslag 36: Afrikaanse Gesinsbeleid.

83. Grootraad van die Ossewa-Brandwag, Gesonde Huisgesinne Bou 'n Lewenskragtige Volk, p 18.

84. OBA: D.J.M. Cronjé-vers., B/L 1/5, omslag 4: Die Ossewa-Brandwag: Vanwaar en Waarheen?, p 26.

85. OBA: D.J.M. Cronjé-vers., B/L 1/5, omslag 4: Die Ossewa-Brandwag: Vanwaar en Waarheen?, p 27.

86. OBA: Die OB, 16 Februarie 1949 en 16 Maart 1949.

87. OBA: Kaaplandse beheerraad-vers., B/L 5(i)/1, omslag 5)

88. Grootraad van die Ossewa-Brandwag, Gesonde Huisgesinne Bou 'n Lewenskragtige Volk, p 20. 
Blignaut \& du Pisani - Organiese nasionalisme en die amptelike gesinsbeleid van die OB

In 'n kort uiteensetting van die gesinsbeleid se vernaamste beginsels word die volgende stelling as kern gebruik wanneer verwys word na die vrou se plek in die samelewing: "Die hoogste taak van die vrou: huishouding, gesinsvorming en opvoeding". ${ }^{99}$ Volgens die $\mathrm{OB}$ se gesinsbeleid het die "liberalistiese en egoïstiese lewensbeskouing", gewortel in kapitalisme, die vrou van haar ereposisie onttroon en van moederskap 'n las gemaak. ${ }^{90}$ Teen die agtergrond hiervan is daar in die vernaamste beleidsbeginsels van die OB bepaal dat die doel van die gesinsbeleid ook is om die eer van die vrou as gesins- en volksmoeder te herstel. ${ }^{91}$ Voorts is daar verklaar: "Volgens hulle onderskeie aard en aanleg het man en vrou in die volkslewe 'n onderskeie, maar wedersyds aanvullende taak en roeping". ${ }^{92}$ Verder is verduidelik: "Omdat man en vrou van nature van mekaar verskil, moet hulle uit die aard van die saak in die volkslewe en gevolglik ook in die volksbeweging elk 'n onderskeie taak hê, net soos dit in die huisgesin die geval is". ${ }^{93}$

Benewens die vrou se "ereplek" in die gesin is daar bepaal dat sy ook 'n bykomende taak in die gemeenskap moet uitvoer, naamlik dié van volksorg. ${ }^{94}$ Dit het vroue se rol in die samelewing laat aansluit by die sosialisme van die OB (die "organiese volksbegrip"). Hierdie begrip is verwoord in die uitlating "almal vir elkeen en elkeen vir almal" wat die fondament van die begrip "volksorg" gevorm het. Hiervolgens het die vrou se taak nie slegs die versorging van haar eie gesin behels nie. Aangesien die gesin 'n maatskaplike funksie het, moes die vrou ook na ander gesinne in nood uitreik. Die OB-vrou moes besef "dat as die een gesin swak is of vir die volk verlore gaan, die volk as geheel daaronder ly". ${ }^{95}$ Volksorg is beskou as die vrou se aandeel aan die "breëre volkslewe". Tog is ook duidelik uitgestippel dat hierdie aandeel as bykomstige taak naas moederskap beskou moet word sodat "haar hoogste roeping daardeur [nie] in die wiele gery word nie". 96

Sodra 'n vrou in die huwelik getree het, moes sy dus aan die beroepsarbeid vaarwel sê. Die man se inkomste moes daarvolgens voldoende wees om die gesin te versorg. Die OB se gesinsbeleid het volgehou dat die staat hiervoor voorsiening moet maak: "Soveel kan gedoen word as die staat sy roeping sien in die volk as organisme en nie net in die beskerming van geldbelange nie. As die volk berus op die gesin moet die staat die gesinslewe aanmoedig en beskerm". ${ }^{97} \mathrm{Om}$ dus die verdeling van arbeid

89. OBA, Grootraad-vers., B/L 1/4, omslag 36: Die Ossewa-Brandwag: Doel en Strewe.

90. OBA, Die $O B, 2$ November 1949.

91. OBA: J.S. de Vos-vers., B/L 1/2, omslag 1: Oorsig van die Vernaamste Beleidsbeginsels van die Ossewa-Brandwag.

92. OBA: Die $O B, 28$ Oktober 1942.

93. OBA: Cronjé, C.-vers., B/L 2/11, omslag 3: Die Vroue-adjunkraad en Vrouevertakking: Verklaring en Besluite

94. Grootraad van die Ossewa-Brandwag, Gesonde Huisgesinne Bou 'n Lewenskragtige Volk, p 20.

95. Grootraad van die Ossewa-Brandwag, Gesonde Huisgesinne Bou 'n Lewenskragtige Volk, $\mathrm{p} 1$.

96. OBA: Die OB, 13 April 1949.

97. OBA: D.J.M. Cronjé-vers., B/L 1/5, omslag 4: Die Ossewa-Brandwag: Vanwaar en Waarheen?, p 26. 
tussen die geslagte te handhaaf, moet die staat optree as beskermheer van gesinne en toesien dat slegs die man as broodwinner van die huisgesin optree. Dit is in hierdie geledere ook as skande beskou indien 'n getroude vrou beroepsarbeid beoefen, aangesien sy só haar hoogste roeping afskeep. ${ }^{98}$ Hierdie roeping het nie net die versorging van die gesin ingesluit nie. Dit het ook die belangrikheid van die vrou se vermoë om kinders te baar sterk in die gesinsbeleid beklemtoon.

Die OB het daarop gewys hoe noodsaaklik groot gesinne in die Afrikanersamelewing is - nog ' $n$ saak waaroor aanhangers van die liberalistieskapitalistiese lewensbeskouing "skimpend" en met afkeur gepraat het.99 Die OBgesinsbeleid het 'n direkte verband getrek tussen nasionalisme en die skep en vorming van 'n groot gesin. Teen die agtergrond van die gesin se plek in die organiese eenheid van die volk het OB-leiers selfs sover gegaan as om te sê "die volksliefhebber beskou dit sy plig om die vader van 'n familie te wees" en "elke vader en moeder van die volk wat gesond is beoog 'n familie van ten minste drie kinders...".100 Die drie kinders is veelseggend, aangesien elke gesin so tot die groei van die Afrikanerbevolking sou kon bydra. Die gesinsbeleid het van die veronderstelling uitgegaan dat die geboortesyfer veral onder die boonste laag van die bevolking daal. Die gevolg hiervan sou 'n verswakking in die gehalte van die Afrikanerbevolking behels - "biologies sowel as ekonomies-maatskaplik". ${ }^{101}$ Die OB se gesinsbeleid het duidelik uitgestippel dat die biologiese funksie van die gesin neerkom op "stelselmatige voortplanting in diens van die gesonde biologiese voortbestaan en groei van die volk". ${ }^{102}$

Die OB se klem op Afrikaners se bevolkingsaanwas was sterk gekoppel aan die vrees dat die blankes in die Suid-Afrikaanse samelewing numeries in die minderheid sal bly. Die rede volgens die OB was dat "die nie-blankes in Suid-Afrika sterker voortplant as die blankes" en hierteenoor is "die voortplantingsyfer onder die blankes in Suid-Afrika ... sterk aan die daal". ${ }^{103}$ Vir die aanwas van die blanke bevolking is die OB se hoop gevestig op niks anders nie as "die wieg van die Afrikanervrou".104

Die OB het gesinsvorming gesien in die lig van die goddelike kultuuropdrag volgens Genesis 2:28 soos hulle dit vertolk het: "Deur die huisgesin moet die mens die eerste deel van sy taak, naamlik om die mensegeslag te bou om daardeur die aarde te bewoon en te bewerk, ten uitvoer bring. Die huisgesin skenk dus die lewe aan elke nuwe geslag in die volkslewe". ${ }^{105}$ In gesinne waar egpare kinderloos was, het dit nie

98. OBA: Grootraad-vers., B/L 1/4, omslag 36: Maatskaplike Vraagstukke: Gesinsbeleid.

99. OBA: Die $O B, 2$ November 1949.

100. OBA: Grootraad-vers., B/L 1/4, omslag 36: Die Sedelike Grondslag van die OB-familie.

101. Grootraad van die Ossewa-Brandwag, Gesonde Huisgesinne Bou 'n Lewenskragtige Volk, pp 16-17.

102. OBA: Grootraad-vers., B/L 1/4, omslag 36: Maatskaplike Vraagstukke: Gesinsbeleid.

103. OBA: Die OB, 23 Maart 1949.

104. OBA: Grootraad-vers., B/L 1/2/12: Notule van vergadering, 28/29 September 1944.

105. OBA: D.J.M. Cronjé-vers., B/L 1/5, omslag 4: Die Ossewa-Brandwag: Vanwaar en Waarheen?, p 25. 
Blignaut \& du Pisani - Organiese nasionalisme en die amptelike gesinsbeleid van die OB

beteken dat die vrou dan tot beroepsarbeid kon toetree nie. Hierdie egpare moes aangemoedig word om kinders aan te neem. Verder moes die staat ook die vorming van groot gesinne aanmoedig deur voordele soos gratis kraamverpleging, mediese dienste aan kinders, kindertoelaes, belastingvoordele vir groot gesinne en selfs die oorweging van 'n ekonomiese beleid waarvolgens die koste van lewensonderhoud verlaag word. ${ }^{106}$ Die staat moes ten alle tye die natuurlike aanwas van die volk beskerm. ${ }^{107}$

Die OB se gesinsbeleid het ook ooreengestem met Stoker se idee dat die volk bestaan uit die organiese bloedband, die organiese kultuurband, die landsband asook die historiese band. In die lig hiervan is in hierdie beleid verklaar dat "[g]esin, bloed en vaderlandse bodem" benewens die Afrikaner se godsdiens en vryheidsliefde die "grootste en heiligste volkserfenis" is. ${ }^{108}$ Langs hierdie kanale is bloedsuiwerheid beskou as die Afrikaner se "veiligste anker vir die bepaling van 'n volk se verhouding tot ander volksgroepe". Die kommandant-generaal van die OB het selfs sover gegaan as om te beweer:

Ons Afrikanerskap is 'n sedelike verpligting wat ons deur Gods Wil opgedra is en wat deur die bloed in ons are tot 'n lotsbestemming geword het wat ons nie kan ontkom nie. Alles kan ons verander, ons klere, ons beroep, ons burgerskap, ons partytrou, maar nie ons bloed nie, want ons bloed is onsself. 109

Die OB se leierskap het daarop gewys dat bloedsuiwerheid vir die Afrikaner "een van die allerbelangrikste kwessies is", dat dit 'n bron van eer en 'n hoogste roeping is, en dat bloedvermenging met nie-blankes “'n gruwel en 'n skande" sou wees. ${ }^{110}$

Die huisgesin was dus vir die OB die ideale instelling om die suiwerheid van die volk se bloed te bewaar. Hierdie samelewing-sel kon verseker dat gemengde bloed nie in die volk opgeneem word nie, maar dat die "bloedmengers tesame met die bloedmengsel uitgewerp word". ${ }^{111}$ Die huisgesin kon egter nie daardie roeping vervul sonder die vrou, as moeder, nie. In hierdie verband is verklaar dat die vrou "meer as iemand anders in staat [is] om die bloedband van haar volk te versterk".112 Die simboliese betekenisse geheg aan reinheid het aan die vrou die taak gegee om ook haar volk se bloed rein te hou. Hierdie simboliese betekenis merk 'n mens op in die volgende aanwyser "die volksliefhebber bewaar as heilig die reinheid van sy moeder, vrou, suster en is hoflik teenoor enige dame". 113

106. OBA: Die OB, 23 Maart 1949 en 30 Maart 1949.

107. De Klerk, "Die Ossewa-Brandwag se Ideaal van 'n Nuwe Samelewingsorde in SuidAfrika”, p 119.

108. OBA: Grootraad-vers., B/L 1/4, omslag 36: Maatskaplike Vraagstukke: Gesinsbeleid, p 23.

109. OBA: Grootraad-vers., B/L 1/4, omslag 36: Maatskaplike Vraagstukke: Gesinsbeleid, p 23.

110. OBA: Die $O B, 25$ November 1942.

111. OBA: D.J.M. Cronjé-vers., B/L 1/5, omslag 4: Die Ossewa-Brandwag: Vanwaar en Waarheen?, pp 25-26.

112. OBA: Die $O B, 25$ November 1942.

113. OBA: Grootraad-vers., B/L 1/4, omslag 36: Die Sedelike Grondslag van die OB-familie. 
Deur die Afrikanervrou se wieg as kern van die gesin te beskou, kon die Afrikaner die bloed van die volk slegs suiwer hou volgens die pad van 'n volk wat uit gesonde huisgesinne met rein moeders bestaan. ${ }^{114}$ Volgens die idee van organiese nasionalisme was die volk daarom nie slegs verbind op grond van bloed nie, maar ook deur die geestelike erfenis van die Afrikanerkultuur. Die vrou binne die OB is die taak opgedra om haar kinders te laat deel in hierdie erfenis deur haar rol as opvoeder in die gesin. Die OB se riglyne vir die opvoeding van seuns en dogters is gebou "op grond van daardie (geslagtelike) verskille". 115 So moes die vrou, as moeder, toesien dat haar seun opgevoed word vir "beroepsvoorbereiding- en beoefening. Spesiale volksdiens, veral in die vorm van hande-arbeid vir 'n minimum tydperk. Militêre opleiding vir 'n minimum tydperk." In die geval van jong meisies moes die moeder veral beklemtoon "dat by haar 'n ontwikkelde vrouelikheid aangekweek moet word ... met die oog op haar eintlike toekomstige taak moet meer nadruk gelê word op gesinsdiens." [sic].116

Die bogenoemde aanwysings stem ooreen met die organiese gedagte wat agter die gesinsbeleid skuil. Dit het neergekom op die gebruik van die gesin as beginpunt en kern waarna verwys is met die oog op die verdeling van arbeid van die volk in die geheelbinne die konteks van organiese nasionalisme en die skewe gebruik van soewereiniteit in eie kring. In die lig van die universalistiese aard van organiese nasionalisme sluit die gesin se arbeid ook dié van die volk in. In hierdie verband word die gesin dus beskou as "die weerspieëling van die volk se arbeidsgemeenskap wat vir homself sorg. Die arbeid van die volk bestaan uit die arbeid van die huisgesinne. 'n Onselfstandige gesin beteken 'n onselfstandige volk". ${ }^{117}$

\section{Gevolgtrekking}

Alhoewel die OB gedurende sy beginjare gekenmerk was deur 'n wasige ideologie wat appelleer het tot die meerderheid nasionalisties-gesinde Afrikaners, is dit duidelik dat namate die tyd verloop het die beweging op sterker ideologiese voet geplaas is. Die OB is beslis beïnvloed deur die ideologiese tydsgees wat in Duitsland en Italië geheers het gedurende die 1930's, maar 'n mens moet versigtig wees om die beweging botweg af te maak as "Nazisties". Dat die OB pro-Duits was, is ongetwyfeld die geval, maar die organisasie se weergawe van nasionaal-sosialisme was eiesoortig tot die Afrikaner. Die Christendom is grootliks in Nazi Duitsland vervolg terwyl die intelligentsia agter die OB die beweging se ideologie, alhoewel skeef, op die Reformatoriese filosofie gebou het. Dit is nie verbasend nie, gegewe die feit dat verskeie akademici van die eertydse PU vir CHO hoë poste in die OB beklee het. H.G. Stoker is sekerlik die beste voorbeeld. Die sogenaamde "organiese" nasionalisme wat OB denkers in nasionaal-sosialisme ingelees het, het goed ingepas by die pluraliteitsbeginsel inherent tot Reformatoriese filosofie. Die abstrahering van die volk tot einde op sigself, en die blinde getrouheid aan hierdie gedagte, is sekerlik

114. Grootraad van die Ossewa-Brandwag, Gesonde Huisgesinne Bou 'n Lewenskragtige Volk, p 23.

115. OBA: Die OB, 13 April 1949.

116. OBA: Die $O B, 13$ April 1949.

117. OBA, Die OB, 20 Mei 1942. 
Blignaut \& du Pisani - Organiese nasionalisme en die amptelike gesinsbeleid van die OB

waar die OB ideologies die meeste ooreenstemming getoon het met Duitsland en Italië. So ook die beskouing van die gesin as sentraal tot die verwesenliking van die onderskeie bewegings se samelewingsideale.

Die groot entoesiasme waarmee die OB ontvang is, het wel later afgeneem, maar dit blyk duidelik te wees dat diegene wat beleid uitgewerk het ernstig was oor die verkryging van 'n republiek sonder die stembus. Dit is juis die OB se publikasie van 'n konsepgrondwet wat uiteindelik gelei het tot die skeur wat plaasgevind het tussen die OB en die Gesuiwerdes. Voorts moes die OB iewers begin met die hervorming van die samelewing. Die gesin was 'n praktiese beginpunt, maar het ook ingepas by die voorgestelde ideologie. Die OB was wel nie die enigste Afrikanerorganisasie wat hierdie sentimente oor die gesin gekoester het nie. Meyer se idees, wat opgeneem is in die gesinsbeleid, sou later manifesteer in die Apartheidsregering. Dit is wel interessant om te sien hoe OB-ideologie ' $n$ belangrike klem geplaas het op die rol van die vrou in gesinsvorming. Hier is 'n mate van historiese kontinuïteit te bespeur wat sover teruggaan as die Groot Trek met die grensboere wat as familie-eenhede getrek het saam met die vroue. Alhoewel die vrou se rol beslis op beperkte wyse geskets is, is sy gesien as sentraal tot die slaag van gesinsvorming wat, volgens die logika van organiese nasionalisme, sou lei tot 'n "gesonde volk".

\section{BRONNELYS}

Coetzer, P.W. en Le Roux, J.H. (reds), Die Nasionale Party, Deel 4: die "Gesuiwerde" Nasionale Party, 1934-1940 (INEG, Bloemfontein, 1986).

Clouser, R.A., The Myth of Religious Neutrality (University of Notre Dame Press, Notre Dame, 2005).

Cronjé G. en Venter, J.D., Die Patriargale Familie (HAUM, Kaapstad, 1973).

De Klerk, P., "Afrikanerdenkers en die Beginsels van die Ossewa-Brandwag”, Joernaal vir Eietydse Geskiedenis, 14, 1 (1989).

De Klerk, P., "Die Ideologie van die Ossewa-Brandwag”, in Van der Schyff, P.F. (red), Die OB: Vuurtjie in Droë Gras (PU vir CHO, Potchefstroom, 1991).

De Klerk, P., “Die Ossewa-Brandwag se Ideaal van 'n Nuwe Samelewingsorde in SuidAfrika", Joernaal vir Eietydse Geskiedenis, 14, 2 (1989).

Diederichs, N., Nasionalisme as Lewensbeskouing en sy Verhouding tot Internasionalisme (Nasionale Pers, Bloemfontein, 1936).

Erasmus, D.F., Die Christelike Huisgesin, Die Ossewareeks no. 3 (Pro Ecclesiadrukkery, Stellenbosch, 1942).

Giliomee, H., "The Growth of Afrikaner Identity", in Beinart, W. and Dubow, S. (eds), Segregation and Apartheid in Twentieth Century South Africa (Routledge, London, 1995).

Giliomee, H., "The Growth of the Afrikaner's Self-concept", in Van der Merwe, H. (ed.), Looking at the Afrikaner Today (Tafelberg, Cape Town, 1975). 
Blignaut \& du Pisani - Organiese nasionalisme en die amptelike gesinsbeleid van die OB

Grootraad van die Ossewa-Brandwag, Gesonde Huisgesinne Bou 'n Lewenskragtige Volk (Pro-Ecclesia, Stellenbosch, 1942).

Harris, E., Nationalism: Theories and Cases (Edinburgh University Press, Edinburgh, 2009).

Keyter, J. de W., Die Huwelik en Gesin, Tweede Trek-reeks, no. VII (Nasionale Pers, Bloemfontein, 1940).

Kotzé, D.N., “Die Christen en sy Vaderland”, Koers, 2, 6 (1935).

Malan, D.F., Afrikaner-volkseenheid en my Ervarings op die Pad Daarheen (Nasionale Boekhandel Beperk, Kaapstad, 1959).

Marx, C., Oxwagon Sentinel: Radical Afrikaner Nationalism and the History of the Ossewa-Brandwag (UNISA Press, Pretoria, 2005).

Meyer, P.J., Die Toekomstige Ordening van die Volksbeweging in Suid-Afrika (Pro Ecclesia, Stellenbosch, 1942).

Meyer, P.J., Die Vooraand van Ons Vrywording: Die Afrikanerdom Één en Verdeeld (ANJ, Kaapstad, 1941).

Moodie, T.D., The Rise of Afrikanerdom: Power, Apartheid, and the Afrikaner Civil Religion (University of California Press, Berkeley, 1975).

Mouton, M., From Nurturing the Nation to Purifying the Volk: Weimar and Nazi Family Policy, 1918-1945 (Cambridge University Press, New York, 2009).

O'Meara, D., Volkskapitalisme: Class, Capital and Ideology in the Development of Afrikaner Nationalism, 1934-1948 (Cambridge University Press, Cambridge, 1983).

Pine, L., Nazi Family Policy, 1933-1945 (Berg, Oxford, 1997).

Smith, A.D., Nationalism: Theory, Ideology, History (Polity Press, Cambridge, 2010).

Stals, E.L.P. (red.), Afrikaners in die Goudstad, Deel 2: 1924-1961 (HAUM, Pretoria, 1986).

Stoker, H.G., "Die Idee van Nasionalisme”, Tydskrif vir Wetenskap en Kuns, 10 (1931).

Stoker, H.G., Die Stryd om die Ordes (Calvyn-Jubileumboekefonds, Pretoria, 1941).

Thompson, L., The Political Mythology of Apartheid (Yale University Press, New Haven, 1985).

Van der Walt, A.H.J., 'n Volk op Trek: 'n Kort Geskiedenis van die Ontstaan en Ontwikkeling van die Ossewa-Brandwag (Kultuur- en Voorligtingsdiens van die Ossewa-Brandwag, Johannesburg, 1941).

Van Rensburg, J.F.J., Die Vooraand van Ons Volkseie Sosialisme: Die Ossewa-Brandwag Tree die Toekoms Tegemoet (Kultuur- en voorligtingsdiens van die OssewaBrandwag, Pretoria, 1943). 